M. OHASHI, C. S. JAMIESON, Y. CAI, D. TAN, D. KANAYAMA, M.-C. TANG, S. M. ANTHONY

J. V. CHARI, J. S. BARBER, E. PICAZO, T. B. KAKULE, S. CAO, N. K. GARG, J. ZHOU*,

K. N. HOUK*, Y. TANG* (SHENZHEN INSTITUTES OF ADVANCED TECHNOLOGY AND SHANGHAI INSITUTE OF ORGANIC CHEMISTRY, P. R. OF CHINA; UNIVERSITY OF CALIFORNIA, LOS

ANGELES, USA)

An Enzymatic Alder-Ene Reaction

Nature 2020, 586, 64-69, DOI: 10.1038/s41586-020-2743-5.

\title{
Identification of the First Enzyme-Catalyzed Alder-Ene Reaction
}

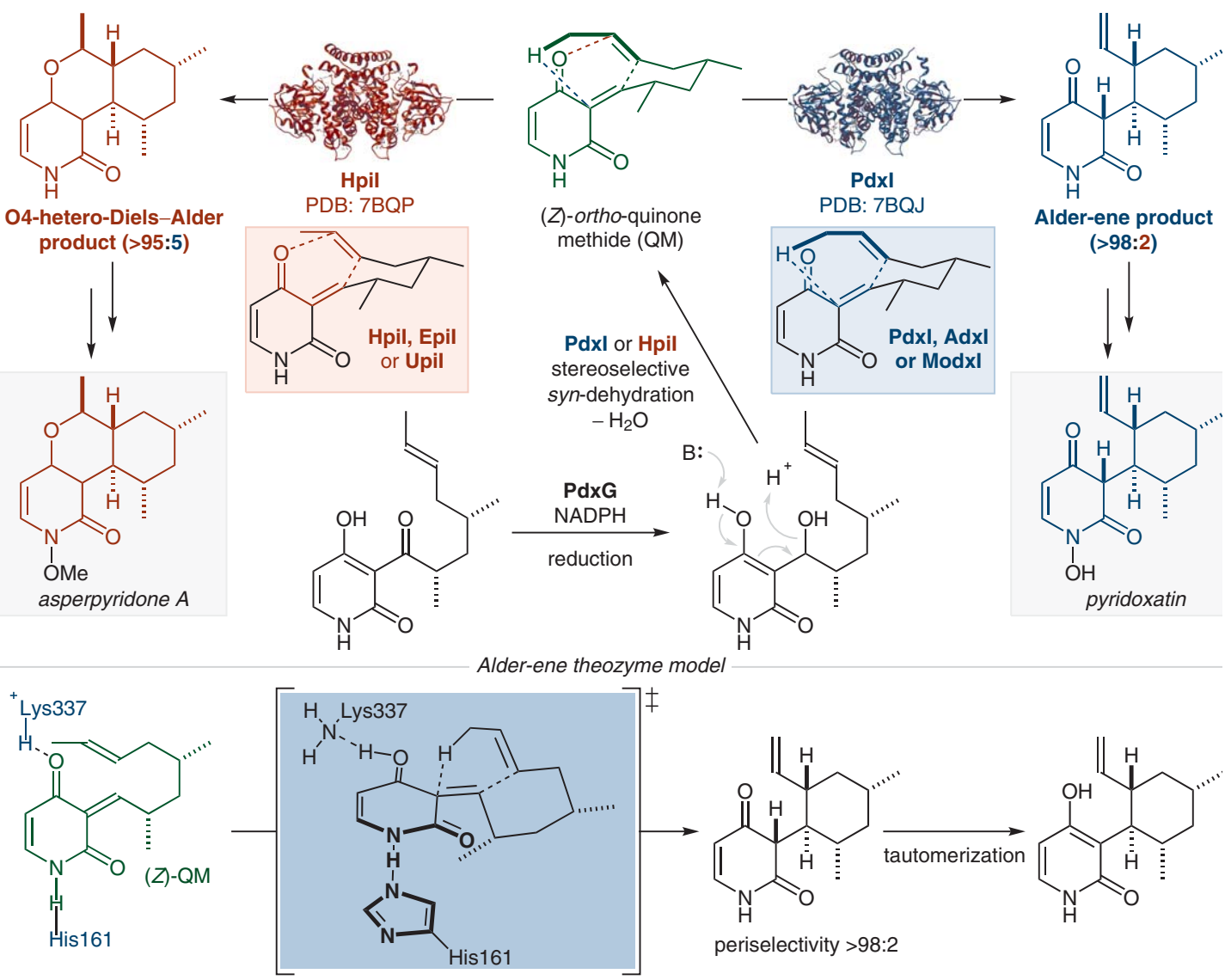

Significance: The groups of Zhou, Houk, and Tang report the discovery of an enzymatic Alderene reaction, involved in the biosynthesis of the leporin 2-pyridone alkaloids pyridoxatin and cordypyridone. The predicted SAM-independent $O$ methyltransferase-fold (OMT-fold) enzymes Adxl, Epil, Pdxl, Modxl, Upil, and Hpil were identified as pericyclase enzymes that catalyze the stereoselective dehydration of the alcohol substrate to a (Z)quinone methide and its subsequent pericyclic transformations. The origin of periselectivity was unraveled by a combination of computational studies, crystallography, and site-directed mutagenesis.
Comment: The authors expanded the array of known pericyclase enzymes by identifying two homologous groups of enzymes that catalyze the same stereoselective syn-dehydration of a pyridone alcohol substrate, but with divergent periselectivity. Crystal structure data of Pdxl and computations suggest that a lysine residue acts as general acid catalyst to favor the Alder-ene over the heteroDiels-Alder pathway. In Hpil, a valine residue in the active site is substituted by a methionine residue that prevents this key interaction thus selectively providing the O4-hetero-Diels-Alder product.

Key words

Alder-ene reaction

hetero Diels-Alder reaction

periselective pericyclase

\section{Synfact
of the Month}

